\title{
PROFILE OF ABDOMINAL TRAUMA PATIENT UNDERWENT SURGERY IN EMERGENCY OPERATING ROOM OF SANGLAH GENERAL HOSPITAL FROM JANUARY UNTIL DECEMBER 2015
}

\author{
Reza Halim ${ }^{1}$, Made Agus Dwianthara Sueta ${ }^{2}$ \\ ${ }^{1}$ General Surgery Training Programme, Faculty of Medicine Udayana University, Sanglah General Hospital, \\ Denpasar, Bali, Indonesia. Correspondence: rzhalim@gmail.com. \\ ${ }^{2}$ Division of Digestive Surgery, Department of Surgery, Faculty of Medicine Udayana University, Sanglah \\ General Hospital, Denpasar, Bali, Indonesia.
}

\begin{abstract}
Objective: to investigate the characteristics of patients, presentation of the abdominal organ that involved, and clinical data associated with this event. Methods: this is a descriptive study with retrospective design. Total samples were all patients with abdominal trauma who underwent surgery on the emergency operating theatre of Sanglah General Hospital between January and December 2015. Baseline data of patients were obtained from the medical records. Results: within the study period, a total of 104 patients with abdominal trauma who underwent surgery in the emergency operating room of Sanglah General Hospital were identified. Man comprised 87.5\% of the patients and mostly were 17-45 years old (75\%). The motor vehicle accident occurred majority on the weekend (65\%). Liver and spleen were the most affected organ (55\%). Splenectomy (35\%) and liver repair surgery (33\%) were the most often performed procedures. Conclusion: Abdominal trauma caused by motor vehicle accident occurred mostly on the weekend. Two most affected organs in abdominal trauma were liver and spleen. Splenectomy and liver repair surgery were the procedures performed for these trauma patients.
\end{abstract}

Keywords: abdominal trauma, patient characteristics, Sanglah Hospital.

\section{PROFIL PASIEN TRAUMA ABDOMINAL YANG MENJALANI OPERASI DI KAMAR OPERASI EMERGENSI DI RUMAH SAKIT UMUM PUSAT SANGLAH DARI JANUARI SAMPAI DESEMBER 2015}

\author{
Reza Halim ${ }^{1}$, Made Agus Dwianthara Sueta ${ }^{2}$ \\ ${ }^{1}$ Program Studi Ilmu Bedah, Fakultas Kedokteran Universitas Udayana, Rumah Sakit Umum Pusat Sanglah, \\ Denpasar, Indonesia. Korespondensi: rzhalim@gmail.com. \\ ${ }^{2}$ Divisi Bedah Digestif, Departemen Ilmu Bedah Fakultas Kedokteran Universitas Udayana, Rumah Sakit \\ Umum Pusat Sanglah, Denpasar, Indonesia.
}

\begin{abstract}
ABSTRAK
Tujuan: untuk mengetahui karakteristik pasien, gambaran organ abdomen yang terlibat, dan data klinis yang terkait dengan trauma ini. Metode: penelitian ini adalah penelitian deskriptif dengan desain retrospektif. Jumlah sampel adalah semua pasien trauma abdomen yang menjalani operasi di kamar operasi emergensi RSUP Sanglah antara Januari sampai dengan Desember 2015. Identitas pasien didapatkan dari rekam medis. Hasil: dalam periode penelitian, terdapat 104 pasien dengan trauma abdomen yang menjalani operasi di ruang operasi emergensi RSUP Sanglah. Pasien laki-laki $87,5 \%$ dan sebagian besar berusia 17-45 tahun (75\%). Kecelakaan kendaraan bermotor banyak terjadi di akhir pekan (65\%). Hepar dan limpa adalah organ yang paling sering cedera (55\%). Sehingga, tindakan splenektomi (35\%) dan perbaikan hepar (33\%) sering dilakukan. Simpulan: trauma
\end{abstract}

1 | Jurnal Bedah Nasional 
abdominal yang disebabkan oleh kecelakaan kendaraan bermotor banyak terjadi akhir pekan. Organ yang paling sering cedera trauma abdomen yang hepar dan limpa. Splenektomi dan perbaikan hepar merupakan prosedur yang dilakukan untuk pasien trauma tersebut.

Kata kunci: trauma abdomen, karakteristik pasien, RSUP Sanglah.

\section{INTRODUCTION}

Trauma is the leading cause of death in this modern era. Trauma involves an exchange of energy that is beyond the body's resilience. Trauma is the most common cause of death for all individuals between 1 and 44 years old and the third most common cause of death regardless of age. ${ }^{1,3}$ Globally, about $10 \%$ of death caused solely by trauma. The U.S. government classified injury-related death into the following categories: accident (unintentional injury), intentional selfharm (suicide), assault (homicide), legal intervention or war, and undetermined cause. Unintentional injuries accounted for over 110,000 deaths per year, and motor vehicle collisions accounted for over $40 \%$. Homicides, suicides, and other causes were responsible for another 50,000 deaths each year. However, death is a poor indicator of the magnitude of the problem, because most injured patients survive. In 2004 there were approximately 167,000 injury-related deaths, but 29.6 million injured patients treated in emergency departments. Injury-related medical expenditures are estimated to be $\$ 117$ billion annually in the United States. ${ }^{2-5}$

The aggregate lifetime cost for all injured patients is estimated to be in excess of \$260 trillion. In Indonesia, along 2013, there were approximately 239.257 types of motor vehicle accidents, with a total loss of IDR 255.864 billion. The morbidity involved 139.898 people and mortality involved 26.146 people. ${ }^{6}$ For these reasons, trauma must be considered as a major public health issue. The American College of Surgeons Committee on Trauma addresses this issue by assisting the development of trauma centers and systems. ${ }^{1,2,5}$

\section{METHODS}

This research is a descriptive study with retrospective design. The population in this study were all patients with abdominal trauma who admitteed to emergency department of Sanglah General Hospital between January and December 2015. The patients' data were identified from the medical records.

\section{RESULTS}

This study was conducted at the Sanglah General Hospital Denpasar on December 2015. Total samples were 104 patients.

From table 1, it was shown that the most prevalent of patients with abdominal trauma that underwent surgery in emergency operating theatre were in the age group of 17-45 years old (75\%). Abdominal trauma occurred more frequently in males $(87.5 \%$; 91 out of $104)$, than female $(12.5 \%$; 13 out of 104). The accident occurred mostly on the weekend 67 cases $(65 \%)$ compared to the non-weekend 37 cases (35\%). Liver and spleen were the most involved organs in abdominal trauma (55\%), followed by stomach and small bowel (15\%), colon and rectal $(12.5 \%)$, duodenum and pancreas 
(9.5\%), and kidneys (8\%). Splenectomy was the most frequent surgical procedure performed (35\%), followed by liver repair surgery $(33 \%)$, stomach and intestines repair surgery (24\%), and nephrectomy $(8 \%)$.

Table 1. Characteristics of the sample

\begin{tabular}{|c|c|c|}
\hline Variable & $\begin{array}{l}\text { Quantity } \\
\text { (Person) }\end{array}$ & $\%$ \\
\hline \multicolumn{3}{|l|}{ Age } \\
\hline$<17$ years & 10 & 9.6 \\
\hline $17-45$ years & 78 & 75 \\
\hline$>45$ years & 16 & 15.4 \\
\hline \multicolumn{3}{|l|}{ Sex } \\
\hline Male & 91 & 87.5 \\
\hline Female & 13 & 12.5 \\
\hline \multicolumn{3}{|l|}{ Day of the accident } \\
\hline $\begin{array}{l}\text { Non-Weekend } \\
\text { (Monday-Thursday) }\end{array}$ & 37 & 35 \\
\hline $\begin{array}{l}\text { Weekend } \\
\text { (Friday-Sunday) }\end{array}$ & 67 & 65 \\
\hline Organ Involved & & \\
\hline \multicolumn{3}{|l|}{ Abdominal Trauma } \\
\hline Liver and spleen & 57 & 55 \\
\hline Stomach and small bowel & 13 & 15 \\
\hline Duodenum and pancreas & 11 & 9.5 \\
\hline Colon and rectal trauma & 14 & 12.5 \\
\hline Kidneys & 9 & 8 \\
\hline \multicolumn{3}{|l|}{ Surgery procedure } \\
\hline Liver repair & 34 & 33 \\
\hline Splenectomy & 36 & 35 \\
\hline $\begin{array}{l}\text { Stomach and Intestines } \\
\text { repair }\end{array}$ & 25 & 24 \\
\hline Nephrectomy & 9 & 8 \\
\hline
\end{tabular}

\section{DISCUSSION}

Traumatic deaths occured at traditionally recognized time points after injury. Approximately half of traumatic deaths occurred within seconds or minutes after injury, which were caused by injury to the aorta, heart, brainstem, or spinal cord or by acute respiratory distress. Unfortunately, very few of these patients could be saved by systems. These issues need the imporovement of injury prevention and control strategies. 5,6
The second mortality peak occured within hours of injury, which accounted for approximately $30 \%$ of deaths. Half of these deaths were caused by hemorrhage and the other half by central nervous system injury. These deaths could be averted by treatment during the golden hour. Trauma system and acute patient care had the greatest impacts on this group of injured patients. Recent analysis of trauma system's efficacy showed more than $10 \%$ reduction of preventable deaths by impoving the trauma systems. In US, there was a significant reduction of mortality by applying statewide trauma system. Nontheless, only approximately $50 \%$ of the United States is served by trauma systems. ${ }^{6}$

The third mortality peak occurred 24 hours after injury, included late mortality from infection and multiple organ failure. Traditionally, these cases accounted for $10 \%$ to $20 \%$ of trauma-related deaths. Recent analysis suggest that the incidence was about $10 \%$. Pulmonary embolism has emerged as an important late cause of death as well. ${ }^{6,9,10}$

Damage control laparotomy is used as a method to save patients with severe injuries, in which the definitive surgical management would not be achieved at the first operation. This was different from the repair all injuries principle applied previously, with the risk of prolonged surgery and physiologic deterioration. Damage control has three phases. In the first phase, an abbreviated operation aims to control bleeding and contamination by rapid surgical maneuvers, including packing, vessel ligation, vessel shunting, bowel resection without anastomosis, and open abdomen. In the second phase, the patient is transferred to the ICU for aggressive resuscitation, rewarming, and 
correction of coagulopathy. The third phase includes return to the operating room to definitive repair of the injuries by reconstituting vascular and bowel continuity, completing the resection of injured organs, unpacking, and closing the abdomen. This third phase may require more than single operation. ${ }^{2,5}$

The principles of damage control surgery have been applied to almost all trauma operation, including laparotomy, thoracotomy, peripheral exploration, and orthopedic procedure. As a concept, it has also been used in resuscitation, angiographic embolization, and organization of surgical combat support. ${ }^{1,2,5}$ The organization of trauma systems has significant favorable impact on patient outcomes. The data records of 2015 from 2755 surgery in the Emergency Operating Room of Sanglah General Hospital, 720 cases were head trauma, 455 cases were extremity fractures, 104 cases were abdominal trauma, the rest were nontraumatic cases. ${ }^{1,2,5}$

\section{CONCLUSION}

Abdominal trauma mostly found in male aged 17-45 years old. Liver and spleen were the most involved organs in abdominal trauma. The most performed surgical procedures were splenectomy followed by liver repair surgery.

\section{REFERENCES}

1. Anonim. Data Register Pasien Trauma di Rumah Sakit Sanglah Denpasar Tahun 2015. Denpasar: Udayana Press; 2015.

2. Cherian A, Udupi BP. Acute coagulopathy of trauma: Mechanism, monitoring, management. World $J$ Anesthesiol. 2014;3:111-8.

3. Biffl WL, Crooke GA, Moore EE.
Trauma. In: Brunicardi FC, Andersen D, Billiar T, et al, editors. Schwartz's Principles of Surgery, Ninth Edition. New York: The McGraw-Hill Companies; 2010. p. 235-395.

4. Tieu BH, Holcomb JB, Schreiber MA. Coagulopathy: Its Pathophysiology and Treatment in the Injured Patient. World J Surg. 2007;31:1055-64.

5. Maegele M, Paffrath T, Bouillon B. 2011. Acute Traumatic Coagulopathy in Severe Injury: Incidence, Risk Stratification, and Treatment Options. Dtsch Arztebl Int. 2011;108:827-35.

6. Mattox KL. 2012. Development of Trauma Care. In: Townsend Jr CM, Beauchamp RD, Evers BM. Sabiston Textbook of Surgery, 19th Edition. Saunders;2012.p. 405-560.

7. Direktorat Jenderal Perhubungan Darat. Perhubungan Darat dalam Angka 2013. Jakarta: Kementerian Perhubungan RI; 2014.

8. Thorsen K, Ringdal KG, Strand K, et al. Clinical and cellular effects of hypothermia, acidosis and coagulopathy in major injury. $\mathrm{Br} J$ Surg. 2011;98:894-907.

9. Eddy VA, Morris Jr JA, Cullinane DC. Hypothermia, Coagulopathy, and Acidosis. Surg Clin North Am. 2000;80:845-54.

10. Widodo SK, Budha K. Pemakaian Sistem Skor untuk Mengukur Angka Kelangsungan Hidup Pasien Trauma Multipel di Rumah Sakit Sanglah Denpasar [tesis]. Denpasar: Universitas Udayana; 2002. 